\title{
AN ANALYSIS ON KRI IMPROVEMENT PROJECT IN INDONESIAN NAVAL MAIN BASE NO. V SURABAYA FASHARKAN (NAVY'S BATTLESHIPS MAINTENANCE AND REPAIRING FACILITIES USING FUZZY FMEA METHOD
}

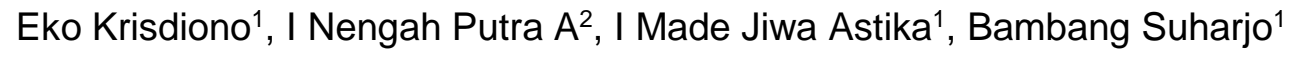 \\ ${ }^{1}$ Indonesian Naval Technology College, \\ STTAL-Bumimoro-Morokrembangan, Surabaya 60187, Indonesia \\ ${ }^{2}$ Indonesia Defense University \\ ${ }^{2}$ Nengah9627@yahoo.com
}

\begin{abstract}
The FMEA method is a tool used to identify the consequences or consequences of a system or process failure and reduce or eliminate failure. In determining risk factors and system improvement priorities, traditional FMEA still has weaknesses, where FMEA traditionally places severity factors, occurrence, and detection at the same level of importance, even though in reality different levels of importance and the importance of FMEA assessment teams are ignored. In this study, the fuzzy method is integrated into FMEA where the severity factor, occurrence, and detection are assessed in linguistic form. In this fuzzy method, the weight of the interests of the FMEA assessment team is taken into account to do ranking and repair priorities. The application of Fuzzy methods to FMEA to determine significant risk factors and prioritizing improvements from various alternatives chosen for the process of repairing $K R I$ in Surabaya Lantamal $V$, so that it is expected that the application of this method can improve the operational performance of Fasharkan to eliminate or reduce the risks that occur in the repair process ships in the eastern region of the fleet.
\end{abstract}

Keywords: Risk Management, Failure Modes and Effect Analysis (FMEA), Fuzzy Method.

\section{INTRODUCTION.}

Indonesian battleship (KRI) as a component of the Integrated Fleet Weapon system (SSAT) is the leading defense force to safeguard the maritime territory of the Republic of Indonesia (NKRI) with all its interests, therefore it requires operational readiness of the $\mathrm{KRI}$ elements. One of the inhibiting factors in $\mathrm{KRI}$ readiness in carrying out operations is the occurrence of a failure in the process of repairing the KRI. Failure on the system will certainly require high costs due to production losses and delays, unplanned interventions in the system and safety hazards (Sachdeva et al, 2009). To prevent these conditions from happening, it is necessary to take the right steps to correct or eliminate failures so that the system's performance does not decrease.

The current conditions for several accidents on the $\mathrm{KRI}$ have caused significant material losses, like KRI Klewang 625 Missile Fast Ship (KCR) which was launched on 31 August 2012 from PT. Lundin Industry Invest Banyuwangi caught fire on Friday 28 September 2012, also KRI Teluk Peleng 535 which sank on Monday 19 November 2013 due to leakage of the vessel's age of 35 years experienced material fatigue and the KRI of Bintuni Bay 520 on October 27, 2014 experiencing a fire caused a problematic electricity on the ship, with these conditions needing 
to identify the risks to the ship to reduce or avoid risks that occur in $\mathrm{KRI}$ making or repairing.

Determining the right steps to prevent failure is not easy. The step combines technical requirements and management strategies (Sachdeva et al, 2009). The failure events in the KRI improvement process are well studied to determine the solutions to be taken based on the form of failure, effects, and costs for all systems. Data information about failure will help personnel determine appropriate corrective actions and determine different priorities on each risk factor which is experience failure.

Based on the Naval Chief of Staff Regulation number Perkasal / 41 / V / 2010 on 18 May 2010, Fasharkan Surabaya is in charge of assisting the Commander of the Surabaya Navy $\mathrm{V}$ Main Base in providing maintenance and repair facilities for ships that will carry out repairs to machinery, equipment navigation, shipping, weapons, electronics, magnetic security, docking and fostering the potential of maritime services supporting the main tasks of the $\mathrm{V}$ Naval Base of Surabaya. In carrying out its duties Fasharkan Surabaya has the function of providing maintenance facilities and improvement for KRI which will carry out repairs, maintain the level of readiness of facilities and infrastructure to be spread out in the Fasharkan environment so that will be able to accept the task of maintaining and repairing the Navy, planning maintenance and repair activities at the depo and middle level as well as emergency repairs to the Eastern Indonesian Fleet Command along with workshop equipment based on the Disharmap Koarmatim plan and program and organizing support for maintenance and repair of unified vessels nonIndonesian Navy as well as commercial vessels in their area by utilizing technology that will be used in the production of ships from the start of design to the operation of the ship.
Risk management is needed to identify strengths and weaknesses for improvements and actions that can be taken to improve performance (Shinyu Mu et al., 2014) Risk analysis is becoming increasingly important now, many cases where failure to manage risk properly can result in considerable losses, both for organizations, even individuals. Several incidents such as losses suffered by companies due to misuse of employees or management, failure to anticipate economic and other crises, there are detrimental to the individual because the individual is negligent in obeying existing regulations. The potential loss from the risk will be even greater if people in the organization (the organization as a whole) do not have prudent behavior. This Incident can be avoided if we understand and manage the risk properly.

Risk response is very important in risk management to produce strategies, use information and knowledge about the problems that have occurred (Zhi-Ping Fan et al, 2015) Risks will arise if there is a deviation outside the plan of an event or a particular situation, the project is an attempt made to take opportunities so that the risk will always accompany it, therefore what needs to be considered is to optimize every opportunity that exists, in addition to taking steps to minimize the negative impact of risk on the goals and objectives to be achieved.

The FMEA method can be used to prevent various forms of failure, estimate problems and find the most optimal solutions economical. The FMEA method can identify potential failure modes in systems, subsystems, and components. This method prioritizes all potential failure modes to determine preventive measures for possible failure.

The application of the Fuzzy FMEA method is to determine the priority of repairs from various chosen alternatives to risks in $\mathrm{KRI}$ improvement 
projects so that it is expected that the application of this method can improve Fasharkan operational performance in carrying out $\mathrm{KRI}$ maintenance and repairs.

\section{MATERIALS/METHODOLOGY.}

\subsection{Failure Mode Effect Analysis (FMEA).}

Failure Modes and Effect Analysis

(FMEA) is a structured procedure for identifying and preventing as many modes of failure as possible. FMEA has some risks related to potential failure and provides a good basis for characteristic classification (Pyzdek, 2002). FMEA is a good help analysis maker in identifying potential failure modes, their causes, and effects. In addition, FMEA assists in making priorities and corrective actions for the failure mode.

The aim of FMEA is to help the analysis to identify and prevent problems that have been identified before the problem occurred. For that purpose, each risk mode failures will be evaluated and prioritized so that corrective action can be taken on different failure modes.

Severity is an assessment of the seriousness of the effects caused. In the sense that each failure that arises will be assessed how much the level of seriousness. There is a direct relationship between the effects and severity. For example, if the effect is a critical effect, then the value of severity will be high. Occurrence is the possibility of a cause that will occur and produce a form of failure during the use of the product.

Occurrence is a rating value that is adjusted to the estimated frequency and or the cumulative number of failures that can occur. Value detection is associated with current control. Detection is a measurement of the ability to control/control failures that can occur. The value of Risk Priority Number (RPN) is a product resulting from the multiplication of severity, incidence, and detection rate. RPN determines the priority of failure. RPN has no value or meaning. This value is used to rank potential process failures.

The value of the RPN can be indicated by the equation as follows:

$R P N=($ Severity $) \times($ Occurrence $) \times($ Detection $)$

\subsection{Fuzzy Theory.}

\subsubsection{Crisp Set (Middle).}

According to Yan et al. (1994), the set of crisp $A$ is defined by the elements that exist in that set. If $a \in A$, then $A$ is 1 . However, if $a \in A$, then $a$ is 0 . Notation $A=\{x / P(x)\}$ indicates that $A$ contains $x$ element with the $P$ property are being true. If $X_{A}$ is a characteristic function $A$ with the character $P$, it can be said that $P(x)$ is true if and only if $X_{A}(x)=1$

\subsubsection{Fuzzy Sets.}

According to Yan et al. (1994), fuzzy sets are based on the idea of extending the range of functions characteristics of the crisp set such that the function will include real numbers at intervals $[0,1]$. The value of membership indicates that an element in the universe of conversation is not only at zero (0) and one (1), but also the value located between them. The truth value of a statement is not only true or false. The value of one (1) indicates true and the value of zero (0) indicates false, but there are still values that lie between true one (1) and false zero (0).

The fuzzy set has two (2) attributes, there are Linguistics and Numeric. Linguistics 
is the naming of a group that represents a certain condition by using natural language, such as high, low, good, big, small. Numeric is a value or number that shows the size of a variable, such as 40, 120 and 325 (Kusumadewi and Purnomo, 2004).

Some things to know in understanding fuzzy systems (Kusumadewi and Purnomo, 2004), are:

a. Fuzzy variable

Fuzzy variables are variables which will be discussed in a fuzzy system.

b. Fuzzy set

A fuzzy set is a group that represents a certain condition in a fuzzy variable.

c. The Conversation of Universe

The conversation of the universe is the whole value that is allowed to be operated in a fuzzy variable. This is a set of real numbers which always increases monotonously from left to right. The universal value of the conversation can be either positive numbers or negative. Sometimes the universe value of this conversation is limited by its upper limit.

d. Domain

The domain of fuzzy set is the entire allowable value in the universe of conversation and may be operated in a fuzzy set. As the universe of conversation, domains are sets of real numbers which always increase monotonously from left to right. Domain values can be either positive or negative numbers.

e. Fuzzification

Fuzzification is a process to convert an input variable from a crisp form into a linguistic variable in the form of fuzzy sets with their respective membership functions.

\subsubsection{Fuzzy Membership Functions.}

The membership function is a curve that shows the mapping of data input points into membership degrees that have intervals between zero (0) to one (1) (Kusumadewi and Purnomo, 2004). To get a fuzzy membership value, the functional approach is used. There are several membership functions that can be used, such as the S-function, the Gauss function, the p-function, the beta function, the triangle membership function, and the trapezoid membership function.

A fuzzy membership function is said to be a triangle membership function if it has three parameters, there are $p, q, r \in R$ with $p$ $<q<r$, and stated by the following rules:

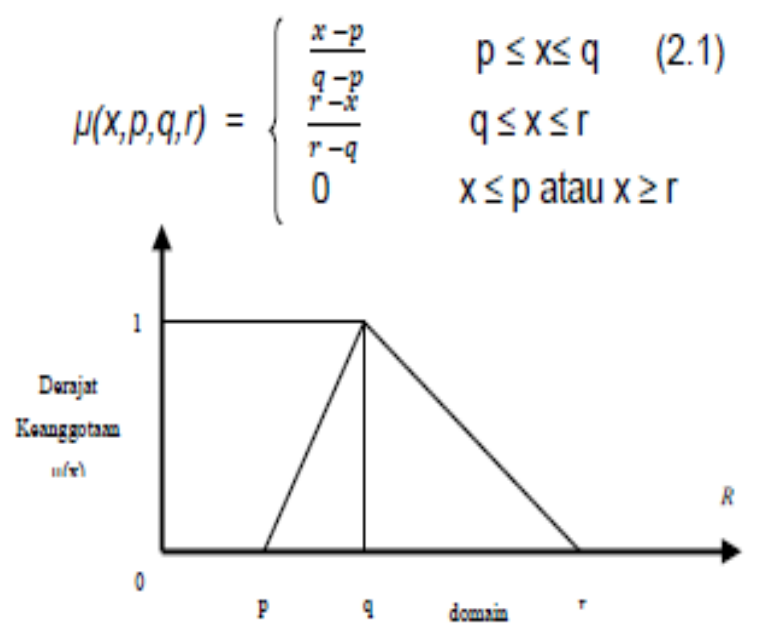

Fig. 1 Triangle Membership function curve (Source: Susilo, 2003).

A fuzzy membership function is called a trapezoidal as membership function if it has four parameters, there are $p, q, r, s \in R$ with $p$ $<\mathrm{q}<\mathrm{r}<\mathrm{s}$, expressed by the following rules: 


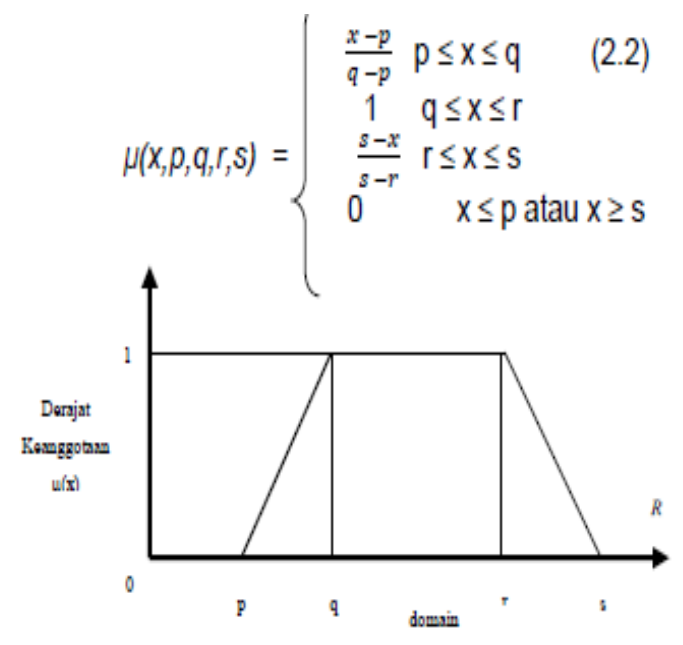

Fig. 2 Trapezoid membership function curve.

\subsection{FMEA based fuzzy.}

Some experts argue that the $\mathrm{S}, \mathrm{O}$ and $\mathrm{D}$ factors are not easily evaluated accurately. Evaluation efforts have done linguistically (Wang et al, 2009). The following table shows the linguistic and fuzzy terms number used to evaluate these factors and visualize the membership function of each of these factors.

Table 1. Fuzzy ratings for severity

\begin{tabular}{|c|c|c|}
\hline Rating & Severity of Effect & $\begin{array}{c}\text { Fuzzy } \\
\text { number }\end{array}$ \\
\hline $\begin{array}{l}\text { Hazardous } \\
\text { without } \\
\text { warning } \\
\text { (HWOW) }\end{array}$ & $\begin{array}{l}\text { Level of brightness is very } \\
\text { high when the failure } \\
\text { model potential affect the } \\
\text { system safety without } \\
\text { warning }\end{array}$ & $\begin{array}{ll}(9, & 10, \\
10) & \end{array}$ \\
\hline $\begin{array}{l}\text { Hazardous } \\
\text { with a } \\
\text { warning } \\
\text { (HWW) }\end{array}$ & $\begin{array}{l}\text { Level of brightness is very } \\
\text { high when the failure } \\
\text { model potential affect the } \\
\text { system safety with warning }\end{array}$ & $\begin{array}{l}(8, \\
10)\end{array}$ \\
\hline $\begin{array}{l}\text { Very high } \\
(\mathrm{VH})\end{array}$ & $\begin{array}{l}\text { The system cannot } \\
\text { operate with failure cause } \\
\text { damage without } \\
\text { endangering the safety }\end{array}$ & $(7,8,9)$ \\
\hline
\end{tabular}

\begin{tabular}{|l|l|l|} 
High $(\mathrm{H})$ & $\begin{array}{l}\text { The system cannot } \\
\text { operate with equipment } \\
\text { damage }\end{array}$ & $(6,7,8)$ \\
\hline $\begin{array}{l}\text { Moderate } \\
(\mathrm{M})\end{array}$ & $\begin{array}{l}\text { The system cannot } \\
\text { operate with minor } \\
\text { damage }\end{array}$ & $(5,6,7)$ \\
\hline Low $(\mathrm{L})$ & $\begin{array}{l}\text { The system cannot } \\
\text { operate without failure }\end{array}$ & $(4,5,6)$ \\
\hline $\begin{array}{l}\text { Very Low } \\
\text { (VL) }\end{array}$ & $\begin{array}{l}\text { The system can operate } \\
\text { with experience having a } \\
\text { significant decline }\end{array}$ & $(3,4,5)$ \\
\hline $\begin{array}{l}\text { Minor } \\
(\mathrm{MR})\end{array}$ & $\begin{array}{l}\text { The system can operate } \\
\text { with experience having } \\
\text { some decline }\end{array}$ & $(2,3,4)$ \\
\hline $\begin{array}{l}\text { Very Minor } \\
\text { (VMR) }\end{array}$ & $\begin{array}{l}\text { The system can operate } \\
\text { with a bit of a nuisance }\end{array}$ & $(1,2,3)$ \\
\hline None (N) & $\begin{array}{l}\text { There is no influence } \\
(1,1,2)\end{array}$ \\
\hline
\end{tabular}

Source : (Wang et al, 2009)

Table 2. Fuzzy ratings for the occurrence

\begin{tabular}{|l|l|l|}
\hline \multicolumn{1}{|c|}{ Rating } & $\begin{array}{l}\text { Probability of } \\
\text { occurrence }\end{array}$ & $\begin{array}{l}\text { Fuzzy } \\
\text { Number }\end{array}$ \\
\hline Very High $(\mathrm{VH})$ & $\begin{array}{l}\text { Failure can't be } \\
\text { avoided }\end{array}$ & $(8,9,10)$ \\
\hline High $(H)$ & $\begin{array}{l}\text { The failure happens } \\
\text { repeatedly }\end{array}$ & $(6,7,8)$ \\
\hline Moderate $(M)$ & $\begin{array}{l}\text { Failure sometimes } \\
\text { times happened }\end{array}$ & $(4,5,6)$ \\
\hline Low $(L)$ & $\begin{array}{l}\text { A little Relative } \\
\text { failure }\end{array}$ & $(2,3,4)$ \\
\hline Remote $(R)$ & $\begin{array}{l}\text { Failure might not } \\
\text { happen }\end{array}$ & $(1,1,2)$ \\
\hline
\end{tabular}

Source: (Wang et al, 2009)

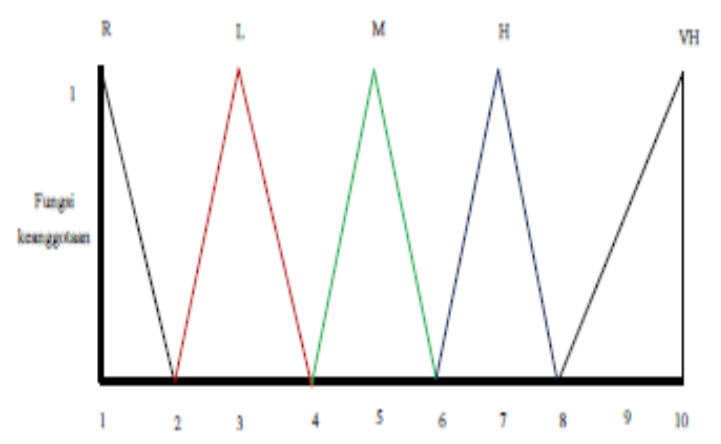

Fig. 3 Occurrence and membership function Fuzzy Values (Source: Wang et al, 2009) 
Table 3. Fuzzy ratings for detection

\begin{tabular}{|c|c|c|}
\hline Rating & $\begin{array}{c}\text { Probability Detection By } \\
\text { controlling device }\end{array}$ & $\begin{array}{c}\text { Fuzzy } \\
\text { Number }\end{array}$ \\
\hline $\begin{array}{l}\text { Absolute } \\
\text { Uncertainty } \\
(\mathrm{AU})\end{array}$ & $\begin{array}{l}\text { There is no controller that } \\
\text { can detect the cause of } \\
\text { failure and the next failure } \\
\text { mode. }\end{array}$ & $\begin{array}{l}(9,10 \\
10)\end{array}$ \\
\hline $\begin{array}{l}\text { Very } \\
\text { remote } \\
(\mathrm{VR})\end{array}$ & $\begin{array}{l}\text { The controlling device has } \\
\text { an extremely narrow ability } \\
\text { in detecting failure causes } \\
\text { and another failure phase }\end{array}$ & $\begin{array}{l}(8,9 \\
10)\end{array}$ \\
\hline $\begin{array}{l}\text { Remote } \\
(\mathrm{R})\end{array}$ & $\begin{array}{l}\text { The controlling device has } \\
\text { the narrow ability in } \\
\text { detecting failure causes } \\
\text { and another failure phase }\end{array}$ & $(7,8,9)$ \\
\hline Very Low & \multirow{2}{*}{$\begin{array}{l}\text { The controlling device has } \\
\text { an extremely narrow ability } \\
\text { in detecting failure causes } \\
\text { and another failure phase }\end{array}$} & \multirow[b]{2}{*}{$(6,7,8)$} \\
\hline (VL) & & \\
\hline Low (L) & $\begin{array}{l}\text { The controlling device has } \\
\text { the narrow ability in } \\
\text { detecting failure causes } \\
\text { and another failure phase }\end{array}$ & $(5,6,7)$ \\
\hline $\begin{array}{l}\text { Moderate } \\
\text { (M) }\end{array}$ & $\begin{array}{l}\text { Failure and another failure } \\
\text { phase. }\end{array}$ & $(4,5,6)$ \\
\hline Moderately & \multirow{2}{*}{$\begin{array}{l}\text { The ability of the device is } \\
\text { on an average level on the } \\
\text { controller detects the cause } \\
\text { of failure and the next } \\
\text { failure mode. }\end{array}$} & \multirow[b]{2}{*}{$(3,4,5)$} \\
\hline High (MH) & & \\
\hline $\operatorname{High}(\mathrm{H})$ & $\begin{array}{l}\text { The high ability of the } \\
\text { controller detects the cause } \\
\text { of failure and failure mode. }\end{array}$ & $(2,3,4)$ \\
\hline $\begin{array}{l}\text { Very High } \\
\text { (VH) }\end{array}$ & $\begin{array}{l}\text { Very high ability of the } \\
\text { controller to detect the } \\
\text { cause } \\
\text { failure and failure mode }\end{array}$ & $(1,2,3)$ \\
\hline $\begin{array}{l}\text { Almost } \\
\text { Certain } \\
\text { (AC) }\end{array}$ & $\begin{array}{l}\text { Almost certainly the ability } \\
\text { of the controller detects the } \\
\text { cause of failure and failure } \\
\text { mode. }\end{array}$ & $(1,1,2)$ \\
\hline
\end{tabular}

(Source: Wang et al, 2009)

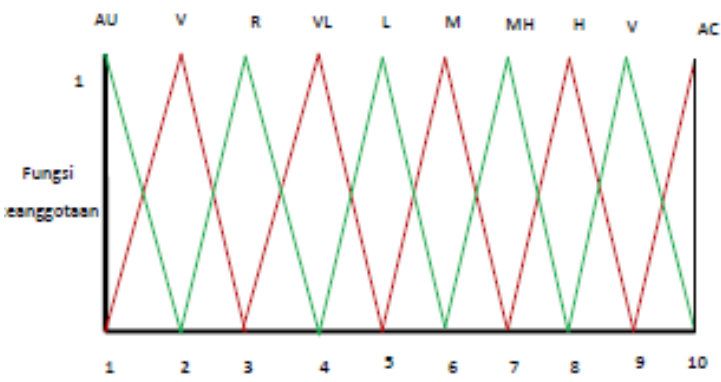

Fig. 4 Detection and membership function Fuzzy

Values (Source: Wang et al, 2009)

Traditional FMEA does not consider the relative importance of risk factors and places them at the same level of importance. The weight of the relative importance of the interests by using linguistic terms that can be seen in table 2.4 and its contribution function can be seen in Figure 2.4.

Table 4. Fuzzy weight for the relative importance

\begin{tabular}{|c|c|}
\hline Linguistic Form & Fuzzy Number \\
\hline Very Low $(V L)$ & $(0 ; 0 ; 0,25)$ \\
Low $(L)$ & $(0 ; 0,25 ; 0,5)$ \\
Medium $(M)$ & $(0,25 ; 0,5 ; 0,75)$ \\
High $(H)$ & $(0,5 ; 0,75 ; 1)$ \\
Very High $(V H)$ & $(0,75 ; 1 ; 1)$ \\
\hline \multicolumn{2}{|c|}{ Source : (Wang et al, 2009) }
\end{tabular}

Based on (Wang et al., 2009) to evaluate the failure factors in FMEA in fuzzy form, steps can be taken as follows:

1. Collect the subjective opinions of members of the FMEA assessment team using the following equation: 


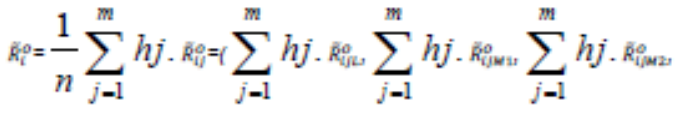

$$
\begin{aligned}
& \sum_{j=1}^{m} h j \cdot k_{i(j u)}^{o}
\end{aligned}
$$

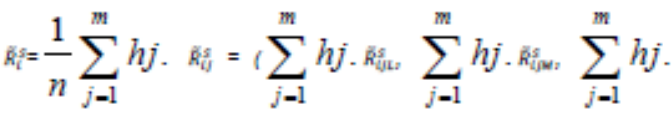



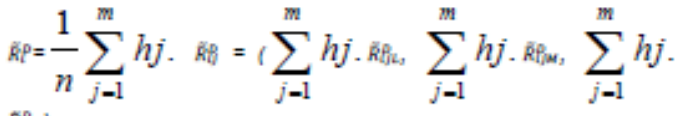

$$
\begin{aligned}
& R_{i, w}^{p j}
\end{aligned}
$$

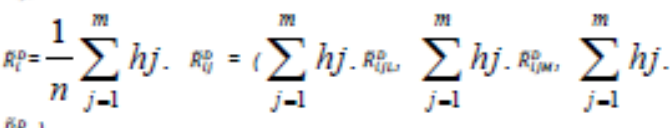

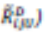



$$
\begin{aligned}
& \text { พิตร) } \\
& \tilde{W}^{s}=\frac{1}{n} \sum_{j=1}^{m} h j . \quad W_{j}^{s}=\left(\sum_{j=1}^{m} h j . \tilde{W}_{\mu}^{s} \sum_{j=1}^{m} h j \cdot \tilde{W}_{j \in}^{s} \sum_{j=1}^{m} h j .\right. \\
& \text { W }
\end{aligned}
$$

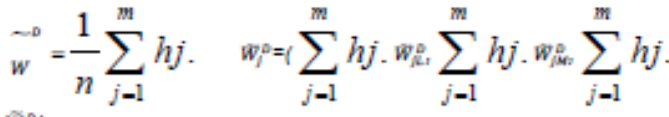

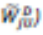

2. Calculates fuzzy risk priority number (FRPN) for each failure model with the following equation:

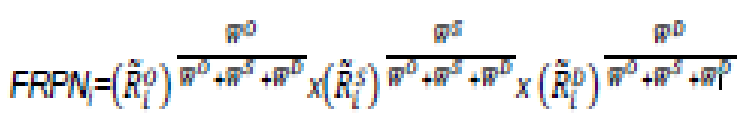

Traditional FMEA defines RPN as a simple result from Occurrence (O), Severity (S), and Detection (D) without considering the weight of its relative importance. But at Fuzzy FMEA weights, the relative importance of risk factors are assessed using linguistic terms.

\section{RESEARCH METHODS.}

This study examines the application of the Fuzzy FMEA method to the improvement of KRI Operational Radar Navigation Sperry Marine Warships of the Republic of Indonesia.

\section{Application of the Model.}

The model implementation will be tested on the Radar Sperry Marine operational process, where

\begin{tabular}{|c|c|c|}
\hline No & Dimension & Failures Modes \\
\hline \multirow{4}{*}{1} & \multirow{4}{*}{$\begin{array}{l}\text { D1 - Force } \\
\text { Majeure }\end{array}$} & D1.1: Fire \\
\hline & & D1.2: Flood \\
\hline & & D1.3: Earthquake \\
\hline & & D1.4: Storm \\
\hline \multirow{3}{*}{2} & \multirow{3}{*}{$\begin{array}{l}\text { D2 - } \\
\text { management }\end{array}$} & $\begin{array}{l}\text { D2.1: Inaccurate from plan } \\
\text { design }\end{array}$ \\
\hline & & D2.2: Supervisor \\
\hline & & \begin{tabular}{|l|} 
D2.3: accuracy for personel \\
selection \\
D2.4: coordination \\
implementation \\
\end{tabular} \\
\hline \multirow[t]{7}{*}{3} & \multirow{7}{*}{$\begin{array}{l}\text { D3- } \\
\text { engineering and } \\
\text { Implements }\end{array}$} & $\begin{array}{l}\text { D3.1: Time accuracy and } \\
\text { job desk }\end{array}$ \\
\hline & & \begin{tabular}{|l|} 
D3.2: accuracy in material \\
execution \\
D3.3: experts availability
\end{tabular} \\
\hline & & $\begin{array}{l}\text { D3.4: Availability of field } \\
\text { workers }\end{array}$ \\
\hline & & U3.5: Lamage trom tools \\
\hline & & $\begin{array}{l}\text { D3.6: Variation in work } \\
\text { Productivity } \\
\text { D3.7: Technology expert in } \\
\text { repairing process } \\
\end{array}$ \\
\hline & & D3.8: Work accidents \\
\hline & & D3.9: Quality of work results \\
\hline \multirow{4}{*}{4} & \multirow{4}{*}{$\begin{array}{l}\text { D4 - Contract } \\
\text { and } \\
\text { law }\end{array}$} & $\begin{array}{l}\text { D4.1: The article is less } \\
\text { complete }\end{array}$ \\
\hline & & D4.2: The article is unclear \\
\hline & & \begin{tabular}{|l|} 
D4.3: Different interpretation \\
D4.4: Payment setting
\end{tabular} \\
\hline & & D4.5: Security problems \\
\hline
\end{tabular}
there are 35 failure modes in the operational process which can be seen in the following table 4.1:

Table 5. Damage Mode 


\section{RESULTS AND DISCUSSION.}

\subsection{Comparative Results of RPN, FRPN.}

Table 6. Comparison of results of RPN, FRPN, and RPI

\begin{tabular}{|c|c|c|c|c|}
\hline No & $R P N$ & FMEA Failures Modes & FRPN & Fuzzy FMEA Failures Modes \\
\hline 1 & 196 & D1.1: Fire & 5,358 & D1.1: Fire \\
\hline 2 & 108 & D1.2: Flood & 4,531 & D1.2: Flood \\
\hline 3 & 40 & D1.3: Earthquake & 3,722 & D1.3: Earthquake \\
\hline 4 & 63 & D1.4: Storm & 3,981 & D1.4: Storm \\
\hline 5 & 216 & D2.1: Inaccurate from plan design & 6,161 & D2.1: Inaccurate from plan design \\
\hline 6 & 100 & D2.2: Supervisor & 6,008 & D2.2: Supervisor \\
\hline 7 & 80 & D2.3: selection & 5,466 & D2.3: selection \\
\hline 8 & 216 & D2.4: coordination implementation & 5,768 & D2.4: coordination implementation \\
\hline 9 & 441 & D3.1: Time accuracy and job desk & 7,501 & D3.1: Time accuracy and job desk \\
\hline 10 & 512 & D3.2: accuracy in material execution & 8,501 & D3.2: accuracy in material execution \\
\hline 11 & 294 & D3.3: experts availability & 7,194 & D3.3: experts availability \\
\hline 12 & 180 & D3.4: Availability of field workers & 6,453 & D3.4: Availability of field workers \\
\hline 13 & 729 & D3.5: Damage from tools & 8,914 & D3.5: Damage from tools \\
\hline 14 & 245 & D3.6: Variation in work Productivity & 6,529 & D3.6: Variation in work Productivity \\
\hline 15 & 216 & D3.7: Technology expert in repairing process & 6,332 & $\begin{array}{l}\text { D3.7: Technology expert in repairing } \\
\text { process }\end{array}$ \\
\hline 16 & 175 & D3.8: Work accidents & 6,275 & D3.8: Work accidents \\
\hline 17 & 120 & D3.9: Quality of work results & 5,847 & D3.9: Quality of work results \\
\hline 18 & 90 & D4.1: The article is less complete & 4,635 & D4.1: The article is less complete \\
\hline 19 & 80 & D4.2: The article is unclear & 4,667 & D4.2: The article is unclear \\
\hline 20 & 36 & D4.3: Different interpretation & 4,002 & D4.3: Different interpretation \\
\hline 21 & 50 & D4.4: Payment setting & 3,243 & D4.4: Payment setting \\
\hline
\end{tabular}

\subsection{RPN, FRPN and RPI Analysis.}

\subsubsection{Analysis of FMEA and FUZZY FMEA.}

In Table 5.1 above we can see that from

22 failure KRI repair models in Fasharkan Lantamal $\mathrm{V}$ Surabaya risk failure groups have the same RPN and ranking values.
From the table above, it can be seen that there are several components that have the same RPN value. This is because, in FMEA traditional factors of severity (S), assurance (O) and detection (D) are considered to have the same level of importance; in fact they have different levels of importance. Likewise, the weight of the 
interests of the FMEA assessment team is not taken into account.

By using a fuzzy approach to FMEA, where each failure has different fuzzy rating values and the level of importance and weight of the FMEA assessment team is considered, then after calculating the FRPN value each component has a different ranking. By using a fuzzy approach to FMEA, it will be more easy for users to distinguish risk in failure mode which has the same RPN value.

\subsubsection{Analysis of FMEA, FUZZY FMEA}

After analyzing the $\mathrm{KRI}$ repair project in Fasharkan Navy Main Base, Surabaya, table 5.1 gives the results of conventional FMEA and fuzzy theory approaches, using the FMEA method makes it difficult for principals to determine the priority order of the failure modes that occur.

From table 5.1 it can also be seen that from the twenty-two failure modes of the KRI repair project in Lantamal V Surabaya there is no same FRPN value for each identified failure mode so that each failure has its own priority rating, this is due to the assessment of severity (S), occurrence and detection (D) factors taking into account the weight of the interests of FMEA assessment team members and the weight of each factor $(S, O$, and $D)$ in each failure mode that occurs.

D2.4 failure mode coordination implementation, D3.7 mastery of technology in the process of improvement and D2.1 inaccurate planning has the same RPN value that is equal to 216 , with the model approach developed, failure modes D2.4, D3.7 and D2. 1 has a different fuzzy rating for each failure mode which is $5.768 ; 6.332$ and 6.161 , by using fuzzy on FMEA it is easier for users to distinguish risk representations in failure mode which has the same RPN value, failure modes D2.4, D3.7 and D2.1 have the same RPN but all three have risks that different, using the proposed method failure modes D2.4, D3.7 and D2.1 have different risk levels and ranking of the three with the proposed approaches, they are 7,9 and 12. Ranking obtained by the FMEA method can result in errors especially if the data used for analysis is accompanied by a high degree of uncertainty.

\section{CONCLUSION.}

From the results of data collection and processing, and analysis and interpretation of the results of data processing that has been done, the conclusions that can be taken in this study are:

a. A significant risk factor in the $\mathrm{KRI}$ repair project in Fasharkan, the Main Navy Base of Surabaya $V$ is

1) Work equipment damage with a value of 8,914

2) The accuracy of material procurement with a value of 8.501

3) Timeliness of work with a value: 7,501

b. Handling the risk response to risks that are likely to occur and have a significant impact on the KRI repair project in Surabaya's Fasharkan Main Base $\vee$ Surabaya is expected to minimize the risks that occur or may be able to eliminate the risk response risk as follows:

1) Working equipment damage is by controlling periodic service on existing equipment, controls the calibration of the equipment that has been used validation and buying new equipment and maintenance regularly to reduce expenditure costs. 
2) The accuracy of material procurement is by using previous historical data to estimate work

3) Timeliness of work is by using time management of project implementation must be done by staff officers with the selection of the right method because it becomes a bond in the contract with a fine who force and carry out overtime work.

\section{Suggestions}

a. In this study, it is better to do hypotheses for more and more mastering respondents who have experience in handling risks that occur in $\mathrm{KRI}$ repair projects in Surabaya's Fasharkan Main Base V Surabaya so the results this research can be used as a reference in implementing projects using risk management in subsequent projects.

b. For the next researchers who are interested in a similar type of research, it is better to develop it by combining with other methods to analyze more complex problems.

\section{BIBLIOGRAPHY.}

Afnor. (2003) Norma FD X 50-117 Management des Risques Project, (Avril, ISSN : 0335-3931).

Anish Sachdeva, Dinesh Kumar, and Pradeep Kumar. (2009) 'Multi factor failure model critically analysis using TOPSIS', Journal of Industrial Engineering International Islamic Azad University, South Tehran: Branch January 2009, Vol. 5, No. 8, 19.

Aprilia Anastasia. (2006) Analisa Faktor - Faktor Risiko pada Inbound Supply dan Relasinya Terhadap Kinerja Operasional Perusahaan Yang Relevan, Tugas Akhir, Surabaya: Teknik Industri FTI ITS.
Chapman, C.B, Ward, S. (2007) Project Risk Management : Processes Techniques and Insight. Scholl of Management, University of Southampton UK 0-470-85355-7.

Conroy, G. Soltan H. (1998) 'A project Specific Risk Management Concept', International Journal of Project Management, 16 (6), 353-366.

Diana, Puspita Sari. (2011) 'Analisa Penyebab Kegagalan Produk Woven Bag Dengan Menggunakan Metode FMEA', Prosiding Seminar Nasional Sains dan Teknologi ke-2 Tahun 2011 Fakultas Teknik Universitas Wahid Hasyim Semarang.

Grant, K.P, Cashman, W.M, Christensen, D.S. (2006) 'Delivering Project on Time', Research and Technology Management, 52-58.

Kusumadewi, S., Purnomo. (2004) Aplikasi Logika Fuzzy untuk pendukung Keputusan, Yogyakarta: Graha IImu.

K. Shahroudi, H. Rouydel. (2012) 'Using a multicriteria decision making approach (ANP-TOPSIS) to evaluate suppliers in Iran's auto industry', International Journal of Applied Operational Research Vol. 2, No. 2, pp. 37-48, July 2012.

Nuri Guntur Perdana, Tri Widodo. (2013) 'Sistem Pendukung Keputusan Pemberian Beasiswa Kepada Peserta Didik Baru Menggunakan Metode TOPSIS". Seminar Nasional Teknologi Informsi \& Komunikasi Terapan', Semarang: 16 November 2013.

Pillay, A., and Wang, J. (2003) 'Modified Failure Mode and Effects Analysis Using Approximate 
Reasoning', Reliability Engineering \& System Safety 139,379 -394.

Pyzdek. (2002) The Six Sigma Handbook, Jakarta: PT.Salemba Patria.

Rakesh. R, Bobin Cherian Jos, George Mathew. (2013) 'FMEA Analysis for Reducing Breakdowns of a Sub System in the Life Care Product Manufacturing Industry, International Journal of Engineering Science and Innovative Technology (IJESIT), Volume 2, Issue 2, March 2013.

Ravendra Singh, Hemant Rajput, Vedansh Chaturvedi, Jyoti Vimal. (2012) 'Supplier Selection By Technique Of Order Preference By Similariry To Ideal Solution (TOPSIS) Method for Automotive Industry', International Journal Of Advanced Technology \& Engineering Research (IJATER), Volume 2, Issue 2, March 2012.

Restu Prabandini. (2005) Analisa Risiko Pada Proses Distribusi Dan Transportasi, Teknik Industri FTI ITS.

Sachdeva, A., Kumar, D., P. (2009) 'Multi Factor Mode Critically Analysis Using TOPSIS', International Journal of Industrial Engineering, Vol. 5, No. 8 pp 1-9.

Shiyu Mu, Hu Cheng, Mohamed Chohr, Wei peng. (2014) 'Assessing risk management capability of contractors in subway projects in mainland China', International Journal Of Project Management 32.452460.

Susilo, F. (2003) Pengantar Himpunan \& Logika Kabur serta Aplikasinya, Yogyakarta: Graha IImu.
Syarifuddin M Parenreng. (2006) Mengelola Risiko Dalam Supply Chain Management : Studi kasus pada PT. INCO Tbk, Soroako, Tesis Teknik Industri FTI ITS.

Ved Parkash, Deepak Kumar, Chandan Kumar, Rakesh Rajoria. (2013), 'Failure Mode and Effect Analysis of Automotive Charging syste', International Journal of Software and Hardware Research Engineering, Volume 1, Issue 3, Nopember 2013.

Yonas Mitiku Degu dan R. Srinivasa Moorthy. (2014), 'Implementation of Machinery Failure Mode and Effect Analysis in Amhara Pipe Factory P.L.C.', American Journal of Engineering Research (AJER) eISSN : 2320-0847 p-ISSN : 2320-0936, Volume-03, Issue-01, pp-57-63.

Wang, Y.M., Chin, K. S., Poon, G. K. K., \& Yang, J.B. (2013), 'FMEA Analysis for Reducing Breakdowns of a Sub System in the Life Care Product Manufacturing Industry', International Journal of Engineering Science and Innovative Technology (IJESIT), Volume 2, Issue 2, March 2013.

Zhi-Ping Fan, Yong-Hai Li, yao Zhang. (2015) Generating project risk response strategies based on CBR : A case study, Expert system with Applications 42. 2870-2883. 